\title{
Interferensi Leksikal Bahasa Inggris dalam Pemakaian Bahasa Indonesia Karyawan Pariwisata
}

\author{
Desak Putu Karmaningsih*, Ni Wayan Arnati \\ Program Studi Sastra Indonesia, Fakultas Ilmu Budaya, Universitas Udayana \\ [desak.karmaningsih@yahoo.co.id], [wynarnati@gmail.com] \\ Gianyar, Bali, Indonesia \\ *Corresponding Author
}

\begin{abstract}
The research is entitled "Lexical Interference in English in Use of Indonesian Language in Tourism Employees in Ubud Subdistrict ". The purpose of this study was to analyze the form of lexical interference and the factors that cause interference lexical English in the use of Indonesian language tourism employees in the District of Ubud.the theory used is the theory of sociolinguistic by Jendra. To achieve these objectives, several methods and technique are used. The source of the data for analysis was the employee tourism conversations in Ubud District with a total of 50 employees. The results of this study are there are lexical forms at the level of words and interference at the level of phrases, categories of words such as nouns, adjectives, and verbs, factors that cause interference such as informants' bilingualism, habit factors that are influenced by the profession, factors in their own language, familiarity factors.
\end{abstract}

Keywords: lexical interference and the factor of interference.

\begin{abstract}
Abstrak
Penelitian ini berjudul "Interferensi Leksikal Bahasa Inggris dalam Pemakaian Bahasa Indonesia Karyawan Pariwisata di Kecamatan Ubud". Tujuan penelitian ini untuk menganalisis bentuk interferensi leksikal dan faktor-faktor penyebab terjadinya interferensi leksikal bahasa Inggris dalam pemakaian bahasa Indonesia karyawan pariwisata di Kecamatan Ubud. Teori yang digunakan adalah teori sosiolingistik yang dikemukakan oleh Jendra. Untuk mencapai tujuan tersebut digunakan beberapa metode dan teknik. Sumber data penelitian ini adalah percakapan karyawan pariwisata di Kecamatan Ubud dengan jumlah data sebanyak lima puluh karyawan. Hasil penelitian ini yaitu terdapat bentuk leksikal pada tataran kata dan interferensi pada tataran frasa, kategori kata seperti nomina, adjektiva, dan verba, faktor-faktor penyebab terjadinya interferensi seperti faktor kedwibahasaan informan, faktor kebiasaan yang dipengaruhi oleh bidang profesi, faktor dalam bahasa sendiri, faktor keakraban.
\end{abstract}

Kata kunci: interferensi leksikal dan faktor terjadinya interferensi

\section{Latar Belakang}

Menurut undang-undang, Pariwisata adalah berbagai macam kegiatan wisata dan didukung berbagai fasilitas serta layanan yang disediakan oleh masyarakat, pengusaha, dan pemerintah 
(UU RI Nomor 10 pasal 1 ayat 3 tentang Kepariwisataan, 2009:2). Kabupaten Gianyar sebagai salah satu kabupaten di daerah Bali dan sebagai pusat kesenian dan budaya di Pulau Bali memiliki banyak daerah tujuan wisata dan objek wisata yang menarik untuk dikunjungi oleh wisatawan.Kabupaten Gianyar memiliki ciri khas tersendiri di desanya untuk menarik wisatawan yang datang. Salah satu tujuan wisata yang terkenal di Kabupaten Gianyar adalah Ubud.Kecamatan Ubud memiliki luas wilayah $42,38 \mathrm{~km}^{2}$ dan memiliki tujuh desa dan satu kelurahan dengan jumlah penduduk 73.350 jiwa, yang terdiri atas 37.030 jiwa laki-laki, dan 36.320 jiwa perempuan(Statistik Bali: Sensus Penduduk 2018).

Berdasarkan uraian di atas, dasar pertimbangan peneliti mengadakan penelitian interferensi ini di Kecamatan Ubud adalah (1) Kecamatan Ubud merupakan daerah pariwisata yang paling populer di Kabupaten Gianyar, (2) masalah interferensi leksikal bahasa Inggris dalam bahasa Indonesia di kalangan mahasiswa belum ada yang meneliti, (3) ada banyak masyarakat yang berkecimpung di dunia pariwisata, di Kecamatan Ubud.

\section{Rumusan Masalah}

Berdasarkan latar belakang yang telah dijabarkan, terdapat tiga masalah yang diteliti. Ketiga permasalahan itu dirumuskan sebagai berikut.

a) Unsur leksikal bahasa Inggris dalam bentuk apasajakah yang berinterferensi ke dalam bahasa Indonesia karyawan pariwisata di Kecamatan Ubud?

b) Unsur leksikal bahasa Inggris dalam kategori apa sajakah yang berinterferensi dalam pemakaian bahasa Indonesia karyawan pariwisata di Kecamatan Ubud?

c) Faktor-faktor apa sajakah yang menyebabkan terjadinya interferensi bahasa Inggris dalam pemakaian bahasa Indonesia karyawan pariwisata di Kecamatan Ubud?

\section{Tujuan Penelitian}

Adapun tujuan penelitian ini sebagai berikut.

a) Untuk menelaah bentuk-bentuk leksikal bahasa Inggris yang berinterferensi ke dalam pemakaian bahasa Indonesia karyawan pariwisata di Kecamatan Ubud.

b) Untuk mengetahui kategori unsur leksikal bahasa Inggris yang berinterferensi ke dalam pemakaian bahasa Indonesia karyawan pariwisata di Kecamatan Ubud.

c) Untuk mengetahui faktor-faktor yang memengaruhi terjadinya interferensi bahasa Inggris dalam bahasa Indonesia karyawan pariwisata di Kecamatan Ubud.

\section{Metode Penelitian}

Metode dan teknik pengumpulan data yang digunakan dalam penelitian ini adalah metode simak dan dilanjutkan dengan tiga teknik untuk mengumpulkan data, yaitu teknik simak libat cakap, teknik rekam, dan teknik catat. Pada tahap analisis data digunakan metode deskriptif kualitatif dan proses penyajian hasil analisis data menggunakan metode informal.

\section{Hasil dan Pembahasan}

\subsection{Kata Dasar}

Kata dasar merupakan kata yang belum mengalami proses morfologis (Sitindoan dalam Dewi, 2010:27).

\subsubsection{Data Kata Dasar}

Club Sandwich itu terdiri dari roti tawar panggang, bacon, telur, selada,mayonaise, keju dan saus tomat. 


\section{Analisisnya:}

Kata dasar tersebut adalah bacon pada

Data di atas padanannya dalam bahasa Indonesia dengan kata babi asap. Setelah digantidata di atas menjadi:

Club Sandwich itu terdiri dari roti tawar panggang, 'babi asap', telur, selada, mayonaise, keju, dan saus tomat.

\subsubsection{Kata Turunan}

Kata turunan merupakan kata yang sudah mengalami proses morfologi (Sitindoan dalam Dewi, 2010:30).

\section{a. Kata Berimbuhan (berafiks)}

Imbuhan (afiks) dalam bahasa Indonesia merupakan bentuk (morfem) terikat yang digunakan untuk menurunkan kata (Alwi dkk., 2000:31).

\section{Data Kata Berawalan (prefiks) /di-/}

Cek file salah satu agar bisa di-rename sesuai kebutuhan.

\section{Analisisnya:}

Prefiks /di-/ dalam bahasa Indonesia berfungsi sebagai pembentuk kata kerja pasif atau dengan kata lain menyatakan suatu tindakan yang pasif (Zaenal, 2009:39). Kata di-rename pada data di atas dalam bahasa Indonesia berarti diberi nama ulang.

\section{b.Kata Berakhiran (sufiks)}

Kata berakhiran (sufiks) merupakan kata berimbuhan yang dibubuhkan di akhir suatu kata dalam pembentukan kata.

\section{Data Kata Berakhiran}

Hari ini kita briefing sebentar saja ya.

\section{Analisisnya:}

Data di atas berasal dari kata dasar brief dan mendapat sufiks -ing dalam bahasa Inggris. Briefing padanannya dalam bahasa Indonesia dengan kata pengarahan singkat.

\subsection{Kategori KataBenda (Nomina)}

Kategori nomina adalah kata yang mengacu pada manusia, binatang, dan bentuk suatu benda, bentuk benda tersebut bersifat, baik abstrak maupun konkret(Alwi, 2010:221).

\section{Data Kategori Kata Benda (Nomina)}

Jumlah customer saat perayaan Natal kira-kira 150 orang.

\section{Analisisnya:}

Kata customer padanannya dalam bahasa Indonesia dengan kata pengunjung. Kata pengunjung dalam kalimat di atas merupakan nomina dalam bahasa Indonesia.

\subsection{Kategori Kata Sifat (Adjektiva)}

Kategori kata sifat (adjektiva) adalah kata yang menerangkan kata benda (Alwi, 2010:221)

\section{Data Kategori Kata Sifat (Adjektiva)}

Di daerah Denpasar udaranya sangat hot.

\section{Analisisnya:}

Pada data tersebut padanan kata hot dalam bahasa Indonesia adalah panas. Kata Hot dalam kalimat di atas merupakan adjektiva dalam bahasa Indonesia.

\subsection{Kategori Kata Kerja (Verba)}

Kata kerja adalah kata yang menyatakan makna perbuatan, pekerjaan, tindakan, proses, atau keadaan (Alwi, 2010:221). 


\section{Data Kategori Kata Kerja (Verba)}

Hari ini kita briefing sebentar saja ya.

\section{Analisisnya:}

Kata briefingpada data di atas padanannya dalam bahasa Indonesia dengan kata pengarahan singkat. Kata pengarahan singkat merupakan verba dalam bahasa Indonesia.

\subsection{Faktor-Faktor Penyebab Interferensi}

\subsubsection{FaktorKedwibahasaan}

Kedwibahasaan informan atau karyawan pariwisata di Kecamatan Ubud merupakan pangkal terjadinya interferensi dan berbagai pengaruh lain dari bahasa sumber, baik dari bahasa daerah, bahasa nasional maupun bahasa asing.

\subsubsection{FaktorKebiasaan BidangProfesi}

Dalam kehidupan sehari-hari yang bersifat resmi atau tidak resmi para informan atau karyawan pariwisata di Kecamatan Ubud selalu menggunakan bahasa sebagai alat komunikasi antarsesama karyawan di lingkungan tempat bekerja. Tanpa disadari komunikasi yang terjadi antarsesama karyawan telah membawa pengaruh terhadap pembendaharaan kata-kata yang digunakan dalam berbahasa.

Berkaitan dengan faktor penguasaan bahasa, yang juga ditunjang oleh kemampuan berbahasa lebih dari satu bahasa, serta dipengaruhi kebiasaan sehari-hari akhirnya bahasa yang digunakan oleh karyawan parwisata bercampur dengan kata-kata atau kaidahkaidah bahasa lainnya, khususnya bahasa Inggris.

\subsubsection{FaktorBahasa Sendiri}

Di samping faktor di atas, terjadinya interferensi juga dapat disebabkan oleh adanya faktor kemudahan-kemudahan dalam bahasa sendiri. Dengan demikian, faktor kemudahan-kemudahan dalam bahasa sendiri dapat menyebabkan unsur bahasa lain mudah masuk atau memengaruhi.

\subsubsection{FaktorKeakraban}

Seseorang yang menguasai bahasa akan menggunakan bahasanya dalam pergaulan, baik di masyarakat maupun di lingkungan tempat bekerja. Jika seseorang menguasai bahasa nasional, bahasa tersebut akan digunakan bergaul secara nasional atau dengan orang dari daerah lain yang berbangsa sama dan memiliki bahasa nasional yang sama. Begitu pula jika seseorang menguasai bahasa asing, dia akan menggunakan bahasa asing. Dalam penelitian ini bahasa Inggrislah yang menjadi bahasa asing yang paling sering digunakan untuk berkomunikasi atau yang berinterferensi ke dalam penggunaan bahasa Indonesia dalam bidang pariwisata.

\section{Simpulan}

Berdasarkan hasil analisis interferensi leksikal bahasa Inggris dalam pemakaian bahasa Indonesia karyawan pariwisata di Kecamatan Ubud dapat disimpulkan sebagai berikut. (1) Interferensi leksikal bahasa Inggris dalam pemakaian bahasa Indonesia karyawan pariwisata di Kecamatan Ubud ditemukan pada dua tataran kebahasaan, yaitu interferensi pada tataran kata dan interferensi pada tataran frasa. Pada tataran bentuk ditemukan enam macam, yaitu kata dasar, kata turunan, kata ulang, kata majemuk, klitik, dan hibrida. (2) Interferensi leksikal berdasarkan kategorinya ditemukan tiga kelas kata (kategori kata). Ketiga kategori kata tersebut adalah kata benda (nomina), kata sifat (adjektiva), dan kata kerja (verba). Interferensi kategori kata benda (nomina) dalam penelitian ini ditemukan sembilan belas data. Interferensi kategori kata sifat (adjektiva) dalam penelitian ini 
ditemukandua jenis, yaitu kata sifat (adjektiva) bentuk tunggal dengan jumlah sepuluh data, dan kategori kata sifat (adjektiva) berbentuk kelompok kata adalah sebanyak delapan data. Interferensi kategori kata kerja (verba) dalam penelitian ini ditemukan sepuluh data. (3) Dalampenelitian yang telah dilakukan melalui pengamatan dengan cara menyimak penggunaan bahasa oleh penutur (karyawan) pariwisata di Kecamatan Ubud, diperoleh data mengenai faktor-faktor penyebab terjadinya interferensi leksikal bahasa Inggris dalam pemakaian bahasa Indonesia yang terdiri atas faktor kedwibahasaan informan, faktor kebiasaan yang dipengaruhi oleh bidang profesi, faktor dalam bahasa sendiri, dan faktor keakraban.

\section{Saran}

Mengingat interferensi merupakan gejala bahasa yang kurang menguntungkan bagi perkembangan bahasa Indonesia, disarankan penanganan atau penanggulangan masuknya unsurunsur bahasa yang kurang menguntungkan bagi bahasa Indonesia lebih ditingkatkan. Perlu diadakan pembinaan pemakaian bahasa Indonesia yang baik dan benar secara khusus kepada karyawan yang bergerak di bidang pariwisata di Kecamatan Ubud.

\section{Daftar Pustaka}

Alwi, Hasan. 2005. Kamus Besar Bahasa Indonesia. Cetakan Ketiga. Edisi III. Jakarta: Balai Pustaka.

\section{Alwi, Hasan dkk. 2010. Tata Bahasa Baku Bahasa Indonesia. Jakarta: Balai Pustaka.}

Arnati, Ni Wayan. 2017. "Interferensii Bahasa Inggris dalam Pemakaian
Bahasa Indonesia di Daerah Pariwisata di Bali”. Prosiding Seminar Nasional Bahasa Ibu (SNBI) X. Denpasar: Universitas Udayana

Aslinda,Leny $\quad 2007$. Pengantar Sosiolinguistik. Bandung: Refika Aditama.

Chaedar, A. Alwasilah. 1985. Sosiologi Bahasa. Bandung: Angkasa Bandung.

Chaer, Abdul. 2008. Morfologi Bahasa Indonesia (Pendekatan Proses). Jakarta: Rineka Cipta.

Chaer, Abdul. 2014. Linguistik Umum. Jakarta: Rineka Cipta.

Dewi, I Gusti Agung Alit Semara. 2010. "Interferensi Leksikal Bahasa Bali dalam Pemakaian Bahasa Indonesia pada Siaran Dialog Interaktif di Radio Republik Indonesia Denpasar". Skripsi Jurusan Sastra Indonesia Fakultas Sastra Universitas Udayana, Denpasar.

Jendra, I Wayan. 2007. Sosiolinguistik Teori dan Penerapannya. Surabaya: Paramita.

Mandia, I Nyoman. 2014. "Interferensi Bahasa Asing Dalam Jurnal Logic Politeknik Negeri Bali”. Soshum Jurnal Sosial dan Humaniora. Volume 4, Nomor 2, Hlm. 77-88. 